
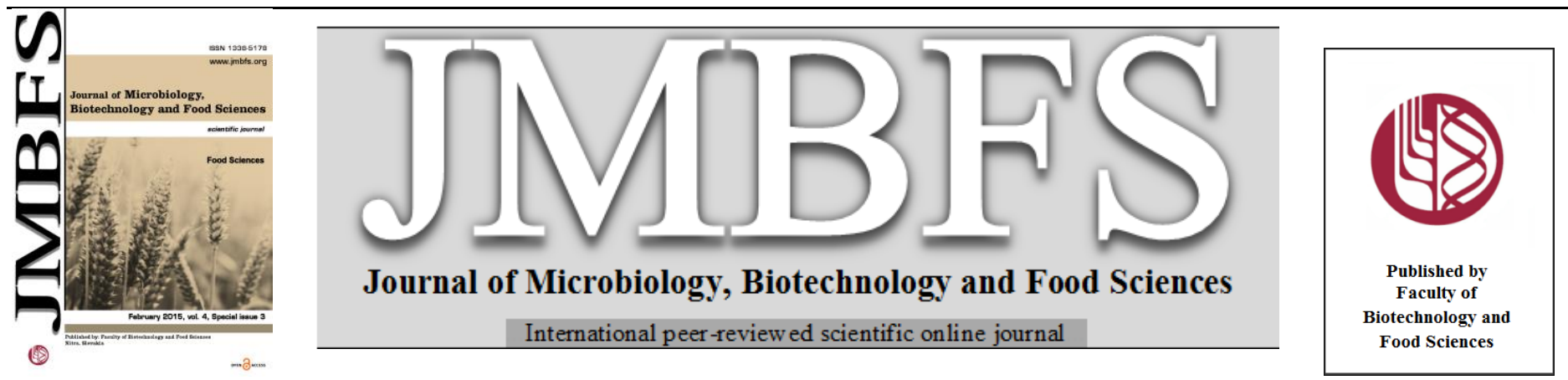

\title{
MILK FATTY ACID PROFILE IN DIFFERENT BREEDS OF DAIRY CATTLE
}

\author{
Katarína Kirchnerová*, Martina Vršková
}

Address(es): Ing. Petra Kavalcová, Katarína Kirchnerová, PhD.

National Agricultural and Food Centre, Research Institute for Animal Production Nitra, Hlohovecká 2, 95141 Lužianky, Slovak Republic, phone number: ++ 4216546 289.

*Corresponding author:kirchnerova@vuzv.sk

doi: 10.15414/jmbfs.2015.4.special3.78-81

\section{ARTICLE INFO}

Received 20.11. 2014

Revised 27. 11. 2014

Accepted 28. 11. 2014

Published 2. 2. 2015

Regular article

OPEN $\partial_{\text {ACCESS }}$

\begin{abstract}
The aim of the paper was to extend the knowledge about current fatty acids (FAs) profile of cow milk fat at herds of cows held in dairy farms in Slovakia. 368 milk samples were taken in total from cows of 5 different breeds, namely Holstein $(H, n=105)$, Red Holstein ( $R$, $n=120)$, Pinzgau ( $P, n=74)$, Slovak Pied $(S, n=61)$, and Braunvieh $(B, n=8)$. Single milk samples were analyzed for fat, protein, lactose content, minerals and fatty acid composition of milk fat using gas chromatography, where 54 FAs were identified and expressed relatively in percentage of peak areas (\%) and evaluated in segments in accord with their biosynthetic origine. The combination of acids C12:0, C14:0 and C16:0, as expressed in the sum HCHFA (46.86\% for S and $47.35 \%$ for P), and also the value of the so-calculated. atherogenic index ( 2.82 for $\mathrm{S}$ and 3.10 for $\mathrm{P}$ ) are the lowest, and thus the most favorable for human health at the breeds $\mathrm{S}$ and $\mathrm{P}$. Medically desirable MUFA (27.11\% for the S and $25.84 \%$ for P) and PUFA (3.55\% for S and $3.26 \%$ for P) in these breeds are represented in the highest percentage shares. We conclude that among the observed breeds of dairy cows the Pinzgau and Simental breeds showed a better value of the composition of milk fat from a health perspective.
\end{abstract}

Keywords: Milk, fatty acids, dairy cattle, breeds

\section{INTRODUCTION}

In recent decades, the intake of milk fat in human nutrition considered a negative factor in relation to cardiovascular disease. Detailed examination, however, brought knowledge of bioactive components in milk fat, which have a beneficial effect on the human body. In particular, the polyunsaturated fatty acids (PUFA) regulate the function of cell membranes and serve as precursors of bioactive mediators. Health effects of essential fatty acids are gaining prominence within the latest medical research, thus recognizing the importance of milk fat in the human diet. The latest research confirms besides of dairy nutrition the importance of genetic effects on the composition of fatty acids in milk fat, and therefore consider it necessary to evaluate this regard at breeds reared in Slovakia.

Capps et al. (1999) described the Jersey breed cows that produce lower levels of conjugated linoleic acid (CLA) than Holstein when they were fed complete feed mixture with the addition of hay. By Palmquist et al. (1993) from Holstein dairy cows produce $8-42 \%$ more short to medium chain fatty acid (C6:0 - C14:0), compared to the Jersey. Jersey dairy cows produced $13 \%$ more stearic acid (C18:0) and less oleic acid (C18:1).

Soyeurt, H. (2010) deals with assessing the breeding value of 1993 bulls based on data corresponding to the number of their daughters (measured by a fast method FTMIR) and states that the heritability of saturated fatty acids (SAFA) and monounsaturated fatty acids (MUFA) were $44 \%$ and $22 \%$, which means that there exists the variability needed for the development of selection in order to improve the nutritional quality of milk fat.

Hanuš et al. $\mathbf{( 2 0 0 8 )}$ found insignificant differences ( $\mathrm{P}>0.05)$ between breeds Czech Pied and Holstein, where SAFA $63.97<65.80 \%$ and unsaturated fatty acids (USFA) $34.62>32.87 \%$. In CLA content there was a clear difference $0.80>0.55 \%$ $(\mathrm{P}<0.05)$. The impact of the level of milk production performance was apparent within breeds $(\mathrm{P}<0.001)$. Czech Pied breed had at a low yield content of CLA $1.14 \%$ and $0.46 \%$ at high. Holstein breed at a high yield $0.72 \%$ and a low $0.39 \%$ CLA in milk fat. High yield decreased content of CLA in milk fat. Czech Pied showed also the difference at the content of PUFA, 4.99>4.12\%. With lower milk yield under the two breeds has always been associated also grazing of cows. Infers that the increased proportion of dry matter originating from roughage is the reason for the increased concentration of CLA and USFA, while a higher proportion of corn feed these components decreases. Therefore, it can be expected a greater percentage of CLA and USFA in milk fat of organically reared grazed animals compared to conventionally farmed. Samková et al. (2012) in comparison of two breeding groups of individual milk samples (Czech spotted, $\mathrm{n}$ $=78$; Holstein, $\mathrm{n}=86$ ) found a difference in the representation of lauric acid (C12: $0,4.69>4.42 \%)$ and palmitic acid $(\mathrm{C} 16: 0,32.75<34.1 \%, \mathrm{P}<0.05)$, and no significant differences in the $\mathrm{C} 18$ acids. An interesting difference (close to statistical significance) was found for the representation of health desirable CLA $(0.42>0.38 \%)$. The mentioned dependence shows that the use of selection for the desired change in the composition of fatty acid profile of milk fat could be possible.

The objective of this paper is the study of the composition of medically important milk fatty acids groups at dairy cows of different breeds in Slovakia

\section{MATERIAL AND METHODS}

The milk samples were taken in total from 368 cows from 11 dairy farms. We followed Holstein $(\mathrm{H}, \mathrm{n}=105)$, Red Holstein ( $\mathrm{R}, \mathrm{n}=120)$, Pinzgau $(\mathrm{P}, \mathrm{n}=74)$, Slovak Pied $(S, n=61)$, and Braunvieh $(B, n=8)$ breed. The dairy cows were at first lactation on different number of days in milk evenly distributed in the interval of 10 - 111 days. The data on their milk performance were processed on the basis of milk recording (The Breeding Services of the Slovak Republic). The milk was sampled from the whole amount of milked milk at regular milk recording. Single milk samples were analysed for fat, protein, lactose content, minerals dry matter (DM), fat free DM (FFDM) and fatty acid composition of milk fat using gas chromatography. (device GC Varian 3800, Techtron, USA) and FID detector in capillary column Omegawax $530 ; 30 \mathrm{~m}$. In the chromatography record were identified 54 fatty acids inclusive of particular isomers. Their representation was expressed relatively in percentage of peak areas (\%). Groups of fatty acids and their abbreviation as well as calculated indexes were created according to traditional structural chemical and nutrition criteria in line with works given in References. The analytical data were assessed professional statistical software SAS version 9.2 (SAS 2002) module in SAS STAT. 


\section{RESULTS AND DISCUSSION}

Quality and production indicators of milk yield at monitored breeds

According to the indicators of milk quality and production (Table 1) can be characterized the production of studied breeds. The average value of the number of days of lactation at the time of sampling is relatively balanced, with no statistically significant differences. Pinzgau breed significantly $(\mathrm{P}<0.001)$ lags behind other breeds in production of milk, fat and protein per day. When
Braunvieh breed reported the highest daily production of milk, fat and protein, followed by Holstein, Red holstein and Simental.

The content of the components of milk (fat, protein, lactose and minerals) is compared with the amount of production typically by reversing. Breeds $\mathrm{B}$ and $\mathrm{H}$ have the lowest fat-free dry matter (FFDM) and total solids in milk, R and S are ranked highest in the FFDM and dry matter content. $\mathrm{P}$ is in the content of dry matter and FFDM in the middle rung.

Table 1 Basic parameters of milk production of studied dairy cattle breeds

\begin{tabular}{|c|c|c|c|c|c|c|}
\hline \multirow[t]{2}{*}{ Breed } & & Braunvieh & Pinzgau & Holstein & Slovak Pied & Red Holstein \\
\hline & $\mathrm{n}$ & 8 & 74 & 105 & 61 & 120 \\
\hline \multirow[t]{2}{*}{ Days in milk D } & $x$ average & 115 & 178 & 170 & 189 & 226 \\
\hline & Sx & 85 & 47 & 89 & 89 & 82 \\
\hline \multirow[t]{2}{*}{ Milk yield kg/D } & $x$ average & $30.31^{\mathrm{ab}}$ & $14.99^{c}$ & $26.31^{\mathrm{a}}$ & $21.86^{b}$ & $23.90^{\mathrm{a}}$ \\
\hline & Sx & 7.44 & 2.92 & 6.89 & 3.80 & 4.38 \\
\hline \multirow[t]{2}{*}{ Fat kg/D } & $x$ average & $1.24^{\mathrm{ab}}$ & $0.57^{\mathrm{c}}$ & $0.99^{\mathrm{a}}$ & $0.86^{b}$ & $0.95^{\mathrm{a}}$ \\
\hline & Sx & 0.29 & 0.11 & 0.29 & 0.19 & 0.20 \\
\hline \multirow[t]{2}{*}{ Protein kg/D } & $x$ average & $0.93^{\mathrm{ab}}$ & $0.49^{c}$ & $0.81^{\mathrm{a}}$ & $0.72^{b}$ & $0.79^{\mathrm{a}}$ \\
\hline & Sx & 0.22 & 0.09 & 0.18 & 0.13 & 0.14 \\
\hline \multirow[t]{2}{*}{ Fat $g / 100 g$} & $x$ average & $3.83^{\mathrm{ab}}$ & $3.73^{b}$ & $3.55^{b}$ & $4.15^{\mathrm{a}}$ & $4.29^{\mathrm{a}}$ \\
\hline & Sx & 0.48 & 0.41 & 0.75 & 0.63 & 0.53 \\
\hline \multirow[t]{2}{*}{ Protein g/100g } & $x$ average & $3.35^{\mathrm{a}}$ & $3.69^{\mathrm{a}}$ & $3.34^{b}$ & $3.64^{\mathrm{a}}$ & $3.68^{\mathrm{a}}$ \\
\hline & Sx & 0.47 & 0.22 & 0.33 & 0.35 & 0.36 \\
\hline \multirow[t]{2}{*}{ Lactose $\mathrm{g} / 100 \mathrm{~g}$} & $x$ average & 4.71 & 4.81 & 4.86 & 4.89 & 4.87 \\
\hline & Sx & 0.19 & 0.10 & 0.17 & 0.23 & 0.15 \\
\hline \multirow[t]{2}{*}{ Minerals g/100g } & $x$ average & $0.68^{a b}$ & $0.71^{\mathrm{a}}$ & $0.68^{b}$ & $0.71^{\mathrm{a}}$ & $0.71^{\mathrm{a}}$ \\
\hline & Sx & 0.04 & 0.02 & 0.03 & 0.04 & 0.03 \\
\hline \multirow[t]{2}{*}{ FFDM g/100g } & $x$ average & $8.73^{\mathrm{ab}}$ & $9.20^{\mathrm{a}}$ & $8.88^{b}$ & $9.25^{\mathrm{a}}$ & $9.26^{\mathrm{a}}$ \\
\hline & Sx & 0.38 & 0.20 & 0.35 & 0.38 & 0.44 \\
\hline \multirow[t]{2}{*}{ DM g/100g } & $x$ average & $12.56^{\mathrm{abc}}$ & $12.94^{b}$ & $12.43^{\mathrm{c}}$ & $13.40^{\mathrm{a}}$ & $13.66^{\mathrm{ab}}$ \\
\hline & Sx & 0.79 & 0.54 & 0.95 & 0.82 & 1.06 \\
\hline
\end{tabular}

Values with different indices are significantly different $(\mathrm{P}<0.001)$

Legend: DM-dry matter, FFDM-fat free DM

Representation of fatty acids and their medically significant groups in milk fat of studied breeds

Technologically, physiologically and nutritionally important fatty acid group and the proportions of the average for the reference breeds of dairy cattle are given in Table 2.

Two basic groups of fatty acids in terms of saturation of chain, SAFA and USFA form an antagonistic relationship represented in milk fat. The order of studied breeds in terms of their content in milk fat is opposite to each other. Breeds $\mathrm{S}$ and $\mathrm{P}$ showed significantly lowest SAFA, due mainly the lowest content of volatile fatty acids (VFA) namely C4:0 - C10:0. It follows that the biosynthesis of the lower fatty acids de novo run at $\mathrm{S}$ and $\mathrm{P}$ at least intense.

Similarly, the combination of acids C12:0, C14:0 and C16:0, as expressed in the sum HCHFA ( $46.86 \%$ for $\mathrm{S}$ and $47.35 \%$ for P), and also the value of the socalculated. atherogenic index ( 2.82 for $\mathrm{S}$ and 3.10 for $\mathrm{P}$ ) are the lowest, and thus the most favorable for human health at the breeds $\mathrm{S}$ and $\mathrm{P}$. Breed $\mathrm{R}$ has the highest content HCHFA (49.44\%) and one of the highest $\mathrm{Al}$ (3.38). The fatty acids of branched chain (BCFA) come from deaminated amino acids that are components of proteins. $\mathrm{P}$ and $\mathrm{S}$ breeds in milk fat have the highest proportion of branched FA (2.22\% and 2.02\%), caused the highest representation C14: 0i, C15: 0ai, C16: 0i and C17: 0i, which suggests the higher utilization of protein as energy source for the biosynthesis of milk fat. Branched chain fatty acids arise by prolongation of chain that arose by oxidative deamination of branched amino acids (Bauman et al., 2006). The lowest daily production of milk, fat and protein of $\mathrm{P}$ and $\mathrm{S}$ breeds indicates their lower energy efficiency in relation to the production of milk. Unsaturated fatty acids (USFA), as compensation of SAFA, have the highest proportion of milk breeds of $\mathrm{S}$ and $\mathrm{P}(30.66 \%$, respectively $29.11 \%$ ). Both ingredients, MUFA (27.11 for the $\mathrm{S}$ and 25.84 for P) and PUFA (3.55 for $\mathrm{S}$ and 3.26 for $\mathrm{P}$ ) in these breeds are represented in the highest percentage shares. Higher organisms are able to incorporate double bonds in molecule by means of dehydrogenating enzyme system and reactions of chain growth (Jenkins and McGuire, 2006).

Essential fatty acids EFA are also the highest represented in the milk of dairy cattle breeds S $(3.33 \%)$ and P $(2.98 \%)$. Of these, the most nutritionally importan conjugated linoleic acid CLA has significantly highest proportion in milk of breeds $\mathrm{P}(0.67 \%)$ and $\mathrm{S}(0.56 \%)$.

It is believed that the establishment of heritability is related to the extension of the ruminal trans-11 C18: 1 and a lower rate of cis-9, trans-11 CLA, and to the amount and activity of the delta9-desaturase in mammary tissue (Kelsey et al., 2003). Medrano et al. (1999) in their work revealed a difference between breeds in the enzyme activity of stearyl-CoA desaturase, which oxidises the palmitic (C16:0) and stearic (C18: 0) acid to palmitoleic (C16:1) and oleic (C18:1) acid and acts in the production of CLA.

$\mathrm{S}$ and $\mathrm{P}$ have among observed breeds the highest content of $\mathrm{n} 3$ acids $(0.81$, respectively. $0.79 \%$ ), and the lowest ratio of $\mathrm{n} 6 / \mathrm{n} 3$ acids (3.14, respectively. 2.32).As these breeds have also the lowest daily production of milk, fat and protein, it can be assumed that there is further the utilization of body fat reserves and resorption of fatty acids from feed and longer develops biosynthesis of shortchain fatty acid from basic building units. 
Table 2 The average chromatography peak area percentage (x) of the content of fatty acids in milk fat of studied dairy cattle breeds.

\begin{tabular}{|c|c|c|c|c|c|c|}
\hline \multirow[t]{2}{*}{ Breed } & \multirow[b]{2}{*}{$\mathrm{n}$} & \multirow{2}{*}{$\begin{array}{l}\text { Braunvieh } \\
8\end{array}$} & \multirow{2}{*}{$\begin{array}{l}\text { Pinzgau } \\
74\end{array}$} & \multirow{2}{*}{$\begin{array}{l}\text { Holstein } \\
105\end{array}$} & \multirow{2}{*}{$\begin{array}{l}\text { Simental } \\
61\end{array}$} & \multirow{2}{*}{$\begin{array}{l}\text { Red holst } \\
120\end{array}$} \\
\hline & & & & & & \\
\hline \multirow[t]{2}{*}{ SAFA } & $\mathrm{x}$ & $74.13^{\mathrm{ab}}$ & $70.89^{\mathrm{ab}}$ & $71.54^{\mathrm{ab}}$ & $69.34^{b}$ & $73.54^{a}$ \\
\hline & Sx & 4.74 & 4.05 & 6.24 & 3.64 & 2.83 \\
\hline \multirow[t]{2}{*}{ VFA } & $\mathrm{x}$ & $14.04^{\mathrm{ab}}$ & $10.51^{b}$ & $12.43^{\mathrm{a}}$ & $10.34^{b}$ & $12.17^{\mathrm{ab}}$ \\
\hline & Sx & 4.62 & 2.63 & 4.09 & 2.75 & 2.70 \\
\hline \multirow[t]{2}{*}{ HCHFA } & $\mathrm{x}$ & $48.03^{\mathrm{ab}}$ & $47.35^{b}$ & $46.68^{b}$ & $46.86^{b}$ & $49.44^{\mathrm{a}}$ \\
\hline & Sx & 6.59 & 4.00 & 5.45 & 3.97 & 3.10 \\
\hline \multirow[t]{2}{*}{ BCFA } & $\mathrm{x}$ & $1.76^{\mathrm{abc}}$ & $2.22^{\mathrm{a}}$ & $1.74^{\mathrm{c}}$ & $2.02^{\mathrm{b}}$ & $1.86^{b}$ \\
\hline & Sx & 0.27 & 0.27 & 0.23 & 0.25 & 0.28 \\
\hline \multirow[t]{2}{*}{ MUFA } & $\mathrm{x}$ & $23.64^{\mathrm{ab}}$ & $25.84^{\mathrm{ab}}$ & $25.66^{\mathrm{ab}}$ & $27.11^{a}$ & $23.58^{b}$ \\
\hline & Sx & 4.57 & 3.44 & 5.75 & 3.10 & 2.49 \\
\hline \multirow[t]{2}{*}{ PUFA } & $\mathrm{x}$ & $2.23^{\mathrm{d}}$ & $3.26^{\mathrm{ab}}$ & $2.80^{c}$ & $3.55^{\mathrm{a}}$ & $2.88^{\mathrm{bc}}$ \\
\hline & Sx & 0.25 & 0.88 & 0.62 & 0.74 & 0.71 \\
\hline \multirow[t]{2}{*}{ USFA } & $\mathrm{x}$ & $25.87^{a b}$ & $29.11^{\mathrm{ab}}$ & $28.46^{\mathrm{ab}}$ & $30.66^{\mathrm{a}}$ & $26.46^{b}$ \\
\hline & Sx & 4.74 & 4.05 & 6.24 & 3.64 & 2.83 \\
\hline \multirow[t]{2}{*}{ n6 } & $\mathrm{x}$ & $1.59^{c}$ & $1.81^{\mathrm{bc}}$ & $1.94^{\mathrm{b}}$ & $2.17^{\mathrm{a}}$ & $1.74^{\mathrm{bc}}$ \\
\hline & Sx & 0.19 & 0.71 & 0.43 & 0.34 & 0.25 \\
\hline \multirow[t]{2}{*}{ n3 } & $\mathrm{x}$ & $0.39^{c}$ & $0.79^{\mathrm{a}}$ & $0.45^{\mathrm{c}}$ & $0.81^{\mathrm{a}}$ & $0.73^{b}$ \\
\hline & Sx & 0.11 & 0.19 & 0.14 & 0.32 & 0.47 \\
\hline \multirow[t]{2}{*}{$\mathrm{n} 6 / \mathrm{n} 3$} & $\mathrm{x}$ & $4.40^{\mathrm{abc}}$ & $2.32^{\mathrm{c}}$ & $4.62^{\mathrm{a}}$ & $3.14^{\mathrm{b}}$ & $3.23^{\mathrm{b}}$ \\
\hline & Sx & 1.21 & 0.64 & 1.31 & 1.37 & 1.42 \\
\hline \multirow[t]{2}{*}{ AI } & $\mathrm{x}$ & $3.41^{\mathrm{ab}}$ & $3.10^{\mathrm{ab}}$ & $3.11^{\mathrm{ab}}$ & $2.82^{\mathrm{b}}$ & $3.38^{\mathrm{a}}$ \\
\hline & Sx & 0.97 & 0.56 & 0.84 & 0.54 & 0.52 \\
\hline \multirow[t]{2}{*}{ EFA } & $\mathrm{x}$ & $2.16^{\mathrm{c}}$ & $2.98^{\mathrm{ab}}$ & $2.71^{\mathrm{b}}$ & $\mathbf{3 . 3 3}^{\mathrm{a}}$ & $2.81^{\mathrm{b}}$ \\
\hline & Sx & 0.23 & 0.84 & 0.62 & 0.65 & 0.65 \\
\hline \multirow[t]{2}{*}{ CLA } & $\mathrm{x}$ & $0.25^{\mathrm{c}}$ & $0.67^{\mathrm{a}}$ & $0.41^{b}$ & $0.56^{\mathrm{a}}$ & $0.41^{\mathrm{b}}$ \\
\hline & Sx & 0.04 & 0.23 & 0.19 & 0.18 & 0.11 \\
\hline
\end{tabular}

Values with different indices are significantly different $(\mathrm{P}<0.001)$

Legend: SAFA-Saturated fatty acids (FA), VFA-Volatile FA, HCHFA-Hypercholesterolaemic FA, BCFA Branched chain FA, MUFA-Monounsaturated FA, PUFAPolyunsaturated FA, AI-Atherogenic index, EFA-Essential FA, CLA conjugated linoleic acid

\section{CONCLUSION}

Butterfat of Pinzgau and Simental breeds stands out compared to other breeds pursued highest values USFA, PUFA, EFA, n3, MUFA, and CLA, which is the highest in Pinzgau breed. These FA are referred to as wholesome ingredients of milk fat. On the other hand, factors known to have adverse health effect heve in these breeds the lowest value compared to other breeds - atherogenic index and the ratio of $\mathrm{n} 6 / \mathrm{n} 3$.

Acknowledgments: This article was written during realization of the project "MLIEKO no. 26220220196" and „CEGEZ no. 26220120073“, supported by the
Operational Programme Research and Development funded from the European Regional Development Fund.

\section{REFERENCES}

BAUMAN, D. E., MATHER, I. H., WALL, R. J., LOCK, A. L. 2006. Major advances associated with the biosynthesis of milk. J. Dairy Sci., 89(4) 12351243. http://dx.doi.org/10.3168/jds.s0022-0302(06)72192-0

CAPPS, V. A., E. J. DEPETERS, S. J. TAYLOR, H. PEREZ-MONTI, J. A. WYCKOFF, AND M. ROSENBERG. 1999. Effect of breed of dairy cattle and dietary fat on milk yield and composition. J. Dairy Sci. 82(1) 45. 
HANUŠ, O.- ŠPIČKA, J.- SAMKOVÁ, E.- VYLETĚLOVÁ, M.- PEŠEK, M.SOJKOVÁ, K.- JEDELSKÁ, R. 2008. Impact of cattle breed and milk yield on fatty acid profile of raw milk. International Conference Proceedings, XXIII Genetic Days, Scientific Pedagogical Publishing, ISBN 80-85645-59-9, South Bohemia University, 67-70.

JENKINS, T. C., MCGUIRE, M. A. 2006. Major advances in nutrition: impact on milk composition. J. Dairy Sci., 89(4) 1302-1310. http://dx.doi.org/10.3168/jds.s0022-0302(06)72198-1

KELSEY, J.A., B.A. CORL, R.J. COLLIER AND D.E. BAUMAN. 2003. The effect of breed, parity, and stage of lactation on Conjugated Linoleic Acid (CLA) in milk fat from dairy cows. J. Dairy Sci. 86 2588-2597. http://dx.doi.org/10.3168/jds.s0022-0302(03)73854-5

MEDRANO, J.F., A. JOHNSON, E.J. DEPETERS, AND A. ISLAS. 1999 Genetic modification of the composition of milk fat: Identification of poly morphisms within the bovine stearoyl-Co-A-desaturase gene. J. Dairy Sci. 82(1) 71.

PALMQUIST, D. L. BEAULIEU, A D., BARBANO, D. M. 1993 Feed and animal factors influencing milk fat compsition. J. Dairy Sci. 76(6) 1753-1771. http://dx.doi.org/10.3168/jds.s0022-0302(93)77508-6

SAMKOVÁ, E.- ŠPIČKA, J.- HANUŠ, O. 2012. Vliv plemene a individuality na složení mléčného tuku skotu. Effect of breed and individuality on milk fat composition. In Farmářská výroba sýrů a kysaných mléčných výrobků IX. Den s mlékem na MENDELU. Brno: MENDELU, 102-105. ISBN 978-80-7375-613-0. SOYEURT, H. 2010. New parameters and analytical challenges for milk recording bz Fourier-Transform Mid-Infrared Spektrometry (FTMIR) Proc. ICAR 37th Annual meeting - Riga, Latvia (31 May - 4 June, 2010) 283-289. 